
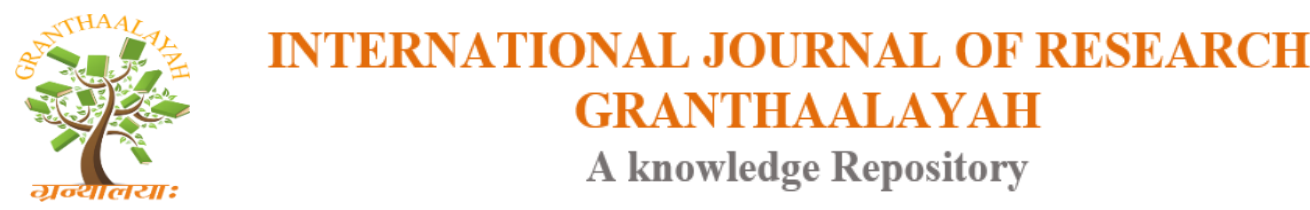

Science

\title{
THE GENERATION OF NEW RESEARCHERS IN THE 21st CENTURY
}

\author{
Alida Bella Vallejo López ${ }^{1}$, Dr Jorge Daher Nader ${ }^{2}$ \\ ${ }^{1}$ MSC Professor Faculty of Medical Sciences, Department of Leveling, University of Guayaquil \\ ${ }^{2}$ MSC Professor Faculty of Medical Sciences, University of Guayaquil
}

\begin{abstract}
In recent times society demands the development and training of professionals capable of investigating, analyzing and solving problems that affect the life of man. Investigate contribute to the progress and development of the countries. However, there are still countries in which the importance or the support that this work deserves has not been given. In Ecuador in the last decade a structure has been established aimed at reaching this goal, but there are still gaps that must be overcome. Objective: The objective of this article is to raise awareness of the importance of forming a new generation of researchers capable of providing scientific knowledge to society and the world ". Methodology. - A review of the literature of the Hinari database, Medline and articles related to the SCIELO, Redalyc Google Scholar web pages. The analysis of 50 found articles was carried out and the article was made based on the information of 12 articles Conclusion Form a new research culture, the key that offers solutions to the problems of humanity to eradicate ignorance and generate prosperity for the peoples of the world.
\end{abstract}

\section{Resumen}

\section{LA GENERACION DE NUEVOS INVESTIGADORES EN EL SIGLO XXI}

En los actuales momentos la sociedad exige el desarrollo y formación de profesionales competentes capaces de investigar, analizar comprender y solucionar problemas que afectan la vida del hombre. Investigar contribuye al progreso y desarrollo de los países. Sin embargo aun existen países en los cuales no se le ha dado la importancia, ni el apoyo que merece esta labor. En Ecuador en la última década se ha establecido una estructura encaminada en alcanzar esta meta, pero aun existen vacios que deben ser superados.

Objetivo.- El presente artículo tiene como objetivo concienciar la importancia de formar una nueva generación de investigadores capaces de aportar con conocimiento científico a la sociedad y al mundo".

Metodología.- Se realiza una revisión de la literatura de la base de datos de Hinari, Medline y artículos relacionados obtenidos de páginas electrónicas SCIELO, Redalyc Google Académico. Se realizo el análisis de 50 artículos encontrados y se procedió a realizar el artículo en base a la información obtenida de 12 artículos

Conclusión Formar una nueva cultura de investigación, es la clave que proveerá las soluciones a los problemas de la humanidad para erradicar la ignorancia y generar prosperidad a los pueblos del mundo 
Keywords: Investigators Health Life Progress.

Cite This Article: Alida Bella Vallejo López, and Dr Jorge Daher Nader. (2018). "THE GENERATION OF NEW RESEARCHERS IN THE 21st CENTURY." International Journal of Research - Granthaalayah, 6(6), 200-204. 10.29121/granthaalayah.v6.16.2018.1366.

\section{Introduction}

In many countries of the world the study of the training and development of researchers is a subject of great relevance, considering it a strategic axis that contributes to the progress and development of the countries. However, there are still countries that have not been given the importance or the support that this work deserves.

Ecuador in the last decade began with several programs aimed at improving the level of educational instruction, both in the primary, and Baccalaureate, while in the Institutions of Higher Education there is still a formal structure for this purpose. In curricular meshes are presented subjects called "research methodology", "only in two semesters of careers in the area of health", there is no continuity in learning for the development of research skills, this reality has been made invisible, by not recognizing the problem that genders in university students who do not master content and research procedures.

This was evidenced by the Higher Education Council in 2014, when I reported that there were 60000 undergraduate graduates who had not graduated until 2008, mostly because they did not finish their thesis project. With this background, the need to strengthen learning for the development of research with the guidance of teachers throughout undergraduate careers can be evidenced.

The educational system has a great challenge in promoting and developing a methodology that entails an education associated with competencies; At present, many schools, colleges, universities are promoting this system, however the results still leave much to be desired in relation to the product we are looking for; the problem is not in a revolution of resources and procedures, but in channeling a revolution in the mind and heart of the human being, that is, generating what the Greeks called the "metanoia", which implies a change of mentality and inner transformation. Terrazas Pastor, Rafael (2013)

The author Fidias G Arias in his work the research project Guide for its elaboration 1999 states: Scientific research is a free and creative process. The man since the beginning of time has been curious, however research empirically does not have a consistent order, always somehow you need an orientation that leads to a consistent planning and order at every step that is necessary to develop procedures what. It requires a research process. In the field of health, as in the social and economic sphere, research and the search for knowledge are key elements that contribute to the progress and development of nations, as manifested at the World Science Conference in 1999. Likewise, the importance of socializing and sharing new knowledge to benefit the entire population of the planet is expressed, the need to work together to grow in knowledge is imposed, in this way we can combat the great scourges of humanity that are ignorance and death, maintaining unity and peace among all countries UNESCO 1999 
The author Ruiz Ramirez, J. (2010) in his work the importance of research considers. The research stimulates critical thinking, creativity and through it, that the learning process is vitalized and memorization is fought, which has contributed so much to forming passive professionals, few lovers of innovation, with little curiosity and personal initiative. Research is of vital importance in postgraduate studies, it is not possible to have high-level graduates if they are not investigated (Ruiz Ramirez, J. 2010).

The thought processes, which generate innovative ideas, need an anchoring point to link the ideas and organize them to generate an essay that meets the characteristics of a scientific text capable of being understood by others interested in the subject. It is necessary to work in the intellectual formation and the awareness of the problems inherent to careers in the health area, the ethical implications and the great responsibility assumed by all aspiring professionals in health with society and humanity. Other important factors that are found in the development of critical thinking, which may be affected by the problem presented.

Develop intellectual agility and problem-solving skills are important to work in the formation of a competent researcher Each person must be responsible for their actions, it is a moral and ethical obligation to be interested in their professional growth on a permanent basis, that makes the difference between a competent worker and an incompetent worker. (Perdomo, \& Martinez 2010). Many undergraduate students have problems in the development of research projects with the intention of obtaining a professional degree, in Ecuador.

The objective of this article is to raise awareness of the importance of forming a new generation of researchers capable of contributing scientific knowledge to society and the world ".

To analyze this issue it must be clear that "Generically, research is an activity of man, oriented to discover something unknown". (Sierra Bravo,1991b, p.27).

In order to train researchers in the new century, emphasis must be placed on the moral and ethical values that imply the handling of information, since there are parameters that are insurmountable, especially when it comes to reporting the results of a study carried out on a person or about a group of people, because you should always take precautionary the privacy and privacy of those involved

Moreno M G in his work the training of researchers as an element for the consolidation of research at the university on overt training; in the training reference is made to the content of the knowledge acquired or to be acquired; training by alludes to procedures or mediations that are used to support the subject that learns; the training to be treated to practice, function or profession that allows the exercise in training. (Moreno et al., 2003, p.52)

The author For Rodriguez I (2012) on this subject state that: "We need to improve our strategies and policies of training, research, innovation, management and financing, eliminating ideological barriers and prejudices, taking advantage of the experiences of success and the opportunities offered in the new technologies "

The increase of scientific knowledge is a necessity in the current world to be able to understand all the processes that are developed daily and that are related to the life and health of man. Research 
is a strategy that allows man to know, investigate, analyze and explain the phenomena that develop around us

In the work of Pérez-Reveles, M et al. (2014) on this subject cite Fortes. In recent years, university education has focused on the training of knowledge-using professionals instead of researchers who produce this knowledge (Fortes, 1991). And they also cite Feldman and Cole who demonstrate. While there are many studies on how science is done, there is little in these works about how students learn science methods through their participation in research groups (Feldman, Divoll and Rogan-Klyve, 2013).

It is necessary a cultural and social transformation from the first semesters of career, avoiding that students assimilate negative attitudes towards a great social responsibility to be health professionals. The practice of human and moral values. Ethics and commitment to humanity on the part of health professionals is an intrinsic value that should be cultivated by making the future health professional more aware of the importance of contributing with possible solutions to the problems inherent to the health of the health. human being, this can only be achieved with new contributions and scientific discoveries that contribute to improving the quality of life of the man to maintain his health in the best conditions, respecting the rights of each person

\section{Conclusion}

The current world advances every day, information and technology change rapidly, hence the importance of being updated and being at the forefront of discoveries in the new century. It should promote strategies aimed at developing scientific competences through the promotion of research, which allow the student to increase knowledge. Fostering a culture of researchers throughout undergraduate careers will help develop skills to work on your thesis. It is important to raise awareness among the authorities and teachers of the Institutions of Higher Education, that in their classrooms the professionals of the future are being trained, who will have to give solutions to the problems that affect the population in the present and in the future. Any educational experience of innovation and research that is carried out results in the welfare of society by increasing scientific production. Based on this reality, it should establish specific programs to promote research at all levels of undergraduate careers, in order to achieve progress in the performance of research projects.

\section{Final Reflection}

The new century and scientific and technological advances require profound changes to form a new generation of researchers who assume the great social responsibility that implies safeguarding the health of patients by providing effective and efficient care, in the best conditions, respecting the rights of each person.

"Encouraging research, to form a new generation of researchers, capable of providing scientific knowledge to society, is an indispensable mission of educational institutions."

Mgs. Alida Vallejo López 


\section{Bibliografía}

[1] Fidias G Arias El proyecto de investigación Guía para su elaboración 1999 Copyright 1999. EDITORIAL EPISTEME, C.A. / ORIAL EDICIONES Caracas-Venezuela Depósito Legal: ISBN 980-07-3868-1

[2] Feldman, A., Divoll, K. A. \& Rogan-Klyve, A. (2013). Becoming researchers: The participation of undergraduate and graduate students in scientific research groups. Science Education, 97, 218-243

[3] Fortes, J. \& Lomnitz, J. (1991). La formación del científico en México: adquiriendo una nueva identidad. México D.F.: Siglo XXI.

[4] Ignacio Para Rodríguez-Santana El Modelo de Futuro de Gestión de la Salud, Propuestas Para Un Debate Editorial Visión Libros, 2012

[5] Moreno Bayardo, M. (2011). La formación de investigadores como elemento para la consolidación de la investigación en la universidad. Revista de la Educación Superior, XL (2) (158), 59-78.. http://www.redalyc.org/pdf/604/60422563004.pdf

[6] Perdomo, Irene Victoria, \& Martínez Calvo, Silvia. (2010). Methodological strategy for the evaluation of professional competencies in Hygiene and Epidemiology specialists. Revista Cubana de Salud Pública, 36(2), 142-147. Recuperado en 11 de enero de 2018, de http://scielo.sld.cu/scielo.php?script=sci_arttext\&pid=S086434662010000200007\&lng=es\&tlng= en.

[7] Pérez-Reveles, M., \& Topete-Barrera, C., \& Rodríguez-Salazar, L. (2014). MODELO PARA LA FORMACIÓN Y EL FORTALECIMIENTO DE INVESTIGADORES EN LAS UNIVERSIDADES. Investigación Administrativa, (114), 82-94. http://www.redalyc.org/pdf/4560/456044957005.pdf

[8] Ruiz Ramírez, Jorge Importancia de la investigación Revista Científica, vol. XX, núm. 2, marzoabril, 2010, pp. 125-126 Universidad del Zulia Maracaibo, Venezuela recuperado de Ruiz Ramírez, J. (2010). Importancia de la investigación. Revista Científica, XX (2), 125-126. http://www.redalyc.org/pdf/959/95912322001.pdf

[9] Sierra Bravo, R. (1988). Tesis doctorales y trabajos de investigación científica (2a ed.). Madrid: Paraninfo. Sierra Bravo, R. (1991 a.). Diccionario práctico de estadística y técnicas de Investigación científica. Madrid: Paraninfo.

[10] Terrazas Pastor, Rafael, \& Silva Murillo, Roxana. (2013). La educación y la sociedad del conocimiento. Revista Perspectivas, (32), 145-168. Recuperado en 07 de mayo de 2018, http://www.scielo.org.bo/scielo.php?script=sci_arttext\&pid=S1994$37332013000200005 \& \operatorname{lng}=\mathrm{es} \& \operatorname{lng}=\mathrm{es}$

[11] UNESCO DECLARACION SOBRE LA CIENCIA Y EL USO DEL SABER CIENTIFICO Adoptada por la Conferencia mundial sobre la ciencia el 1o de julio 1999 - Texto final http://unesdoc.unesco.org/images/0012/001229/122938so.pdf

[12] VÁZQUEZ LEÓN, L. (1996). Reseña de "La formación del científico en México. Adquiriendo una nueva identidad" de Jacqueline Fortes y Larissa A. Lomnitz. Alteridades, 6 (11), 113-117 http://www.redalyc.org/comocitar.oa?id=74711339011

\footnotetext{
*Corresponding author.

E-mail address: alida.vallejol@ug.edu.ec/ositos_3@yahoo.es / jorge.dahern@ug.edu.ec
} 